\title{
SECURITY RISKS RELATING TO THE MIGRANT CRISIS AND INTERAGENCY COOPERATION: THE CASE OF MACEDONIA AND BULGARIA
}

\section{Chris DELISO}

\begin{abstract}
The migrant crisis in the Balkans from 2015-2016 is examined as an example of a hybrid-warfare scenario in contemporary Europe that demonstrates how institutionally-driven security responses that can be applied to successfully counter hybrid threats. Analyzing the experience of Macedonia and Bulgaria, the author identifies five types of security threats that were witnessed along the Balkan route during the migrant crisis. Migrant flows can be infiltrated by potential terrorist for the purposes of simple transit and/or attack scenarios. Organized crime, e.g. by combining human trafficking with other illegal activities, is the second security risk. Thirdly, hostile intelligence penetration of migrant inflows was a very serious hybrid threat, given the opacity of the phenomenon, i.e., the inability to distinguish 'who is who' and what their intentions are. Fourth, the presence of pro-migrant activist and anarchist groups with a track record of violent behavior was a persistent threat as it could be multiplied by participation of large numbers of migrants in concentrated efforts against state borders. Finally, the security situation was affected by the important, and yet often forgotten, psychological warfare.
\end{abstract}

Keywords: Illegal migration, hybrid threats, terrorism, organized crime, psychological warfare, interagency cooperation.

\section{Introduction}

The 2015 migrant crisis on the 'Balkan Route' affected Greece, Macedonia, Serbia and, to a lesser extent, Bulgaria. Under an unprecedented stream of incoming migrants from various countries and cultural backgrounds, these states were overwhelmed by the sheer numbers of people passing through. This phenomenon created ideal conditions for asymmetric threats, such as terrorist penetration, which would emerge later and in other locations (such as the Paris attacks), as well as local destabilization (such as bottlenecks at border crossings). All of these created the conditions for various forms of hybrid war from a variety of actors. As such the case of the migrant crisis in the Balkans represents an excellent case of a hybrid-war scenario in 
contemporary Europe, as well as the kind of institutionally-driven security responses that can be applied to counter successfully such threats.

\section{The Migrant Crisis and State Security Reactions- Institutional Respons-} es

The cumulative security risks involving the migrant crisis can only be understood in the context of the related events of 2015 in Macedonia and the region. By the summer of 2015, Macedonia had survived two security events. The political crisis, which began in January 2015 with the so-called wiretap scandal that paralyzed the government, caused uncertainty, and led to the increasingly heavy involvement into politics of Western embassies and the EU technical experts. The political crisis also exacerbated the pre-existing partisan tendencies in society and activities of 'civil society' groups acting in an increasingly asymmetric way by spring 2016.

The second security event that created the context for national security response was a special police action in May, which neutralized an Albanian terrorist cell organized from Kosovo. If this measure had not been taken, the terrorist group could have destabilized the country by making attacks in public spaces in several cities. Thus, the success of the operation preserved Macedonian territorial integration and operational capability, in terms of securing borders and allowing the orderly processing of migrants.

The twin threats of migration at the southern border, and terrorist groups from the north, in Kosovo (where NATO maintains a presence), revealed a disturbing reality: all national security threats were coming from EU or NATO controlled territory. At the same time, security officials had not received significant help from either. This realization created the conditions for a more direct approach.

The Migration Crisis resulted in a need for a threat assessment in Macedonia during the summer of 2015. The political stalemate in Macedonia changed the capacity of leadership, with the institutional role being taken by President Ivanov, as Commander-in-Chief, becoming the key decision-maker. Macedonia's institutional response followed the law on crisis management, which mandates specific procedures. These procedures kicked in following the declaration of the crisis situation in August.

First, a risk assessment group delivered a report identifying the security threats and risks to a crisis-management Steering Committee, which then gave its proposal to the president, the government (which has responsibility for finances) and the ministries of interior, defense, labor, transport and health, as well as to those municipalities affected by the crisis situation. As head of the National Security Council, President Ivanov then tasked the army with securing and protecting national borders and supporting police there. The fact that the state response was based on rule of law, institutional 
procedures and a broad-based number of individuals and groups eliminated the potential for politicization or partisan behavior. This would be crucial at any time, but particularly in the year of political crisis it became especially important.

\section{Preparations for Dealing with Threats (November 2015)}

The Paris attacks of November 13 caused a National Security Council meeting and decisions, regarding proposals already planned since the August crisis situation declaration. The first was to build a border fence with Greece, and to entirely close the migrant route when northern neighbors decided to do the same. Thirdly, it was decided to increase bilateral cooperation with specific EU and non-EU states, and limit refugee arrivals by countries at war (i.e., not economic migrants).

The fourth decision reached was to push the EU for aid during the imminent visit of EC President Donald Tusk. Finally, security officials had to anticipate hybrid threats that would occur after the closure of the border.

\section{Macedonian Understanding of Migration as a National Security Threat and other Factors Conditioning the Official Response}

The understanding of migration specifically as a national security risk, at a relatively early time, was uncommon among European countries, but in this Macedonia (and countries like Hungary) proved to be astute predictors of the eventual threats of what much of Europe had considered a humanitarian issue. Analysis that 'pro-refugee' European countries would change policies within a year was made by the security officials in Macedonia, and again this was proven an accurate estimate. Bulgaria was relatively not affected by the main migrant streams, though it had to defend its borders as well and thus began a greater interagency cooperation with Macedonia from the fall of 2015 onwards.

Secondly, the awareness that as a 'third country' Macedonia could not expect much EU support (like Turkey and Serbia) affected the response. This meant that such nonEU states could not access the EURODAC database, and security data cooperation with the EU was very poor for much of the crisis. In fact, high-level sources in the security field that the EU was primarily not interested in receiving such information, which ultimately had negative impact on the latter countries being terrorist targets. When cooperation did occur, it was mostly on a bilateral basis with interested nations, which was in some respects a sign of progress, but also indicative of a lack of unified response.

A third factor was the demonstrated lack of Greek police cooperation, and particularly on the border at Gevgelija/Eidomeni. At the peak of the crisis, this meant an unpredictable number of migrants who were poorly or not at all vetted. In December 
2015, Macedonian authorities confronted the European Council President Donald Tusk, the head of Frontex and other officials with the fact that only 8 percent of incoming migrants had been registered by Frontex authorities in Greece in the previous three months. Further, many of these registrations were done erratically or falsely, while Macedonian police had seized thousands of fake Syrian passports of migrants. This revelation did force better cooperation from Greece, but by early spring 2016 the situation had changed; with the closure of the Balkan Route a bottleneck formed on the border, creating conditions for new types of hybrid threats.

Another official concern was that the EU and international agencies such as the UNHCR would request Macedonia to create migrant camps hosting large numbers of migrants was revealed in discussions with these bodies in the fall of 2015. Noting the experience of countries such as Greece and France with large-scale migrant campsand the negative security consequences these structures brought-Macedonia was determined not to accept such proposals. Therefore, only small-scale transit centers were permitted. Bulgaria, as an EU member, had less sovereign capacity to entirely limit these camps, but also looked at them correctly as a security threat and tried to avoid the excessive foreign demands to the extent possible.

A final consideration was that Macedonian officials were confident that the existing national legal infrastructure was capable of defending the border. The rapid reaction of August 2015, at a politically volatile time when many foreign observers were not expecting a resilient response, had been a sort of 'stress test' that the country had passed.

\section{Types of Hybrid Threats in Migration Context}

There are at least five types of security threats related to hybrid war that a variety of actors can exacerbate, individually or in tandem. All of these were witnessed along the Balkan route during the migrant crisis.

First, potential terrorist infiltration of migrant flows (for simple transit and/or attack scenarios) was a major one that was proven in the aftermath of the Paris and Brussels attacks. The investigations revealed that some of the attackers or logistics colleagues had accessed Western Europe disguised as refugees on the Balkan Route. Two others who had planned to travel to Paris were detained by Greek authorities. Terrorist actors infiltrating migrant flows were expedited by the sheer volume of travelers (making detection more difficult) and restriction of 'third countries' on accessing and sharing intelligence with EU members. In this case Bulgaria had an advantage, being an EU and NATO member, but it also was not heavily affected by the migrant flows, thus having less of a threat. 
The second security risk was obviously organized crime (human traffickers with other illegal activities also performed). This involved sophisticated international criminal networks, often with violent capabilities, and represented a constant threat across the length of the border (though concentrated in certain areas).

Thirdly, hostile intelligence penetration of migrant inflows was a very serious hybrid threat, given the opacity of the phenomenon (i.e., the inability to distinguish 'who is who' and their intentions). In such a scenario, analyzing security events became complicated by a high degree of uncertainty. The fact that foreign agencies could instrumentalize not only migrants, but aid workers, journalists, anarchists and activists compounded the complexity of the threat.

Fourth, the presence of pro-migrant activist/anarchist groups with violent goals was a persistent threat as it could be multiplied by participation of large numbers of migrants in concentrated measures against state borders.

Finally, an important but often forgotten concept that affected the security situation of the state was psychological warfare. This affected all states where migrants were trying to enter, like Macedonia, Greece, Bulgaria, Italy and so on. The PsyOps component of this threat amounts to a weaponization of the media against national interests by outside parties having a political or financial interest in negative media depictions.

\section{Security Events involving Hybrid Threats in the Case of Macedonia}

Two key examples revealed the extent of these hybrid threats during the migrant crisis. Both emerged from Eidomeni and targeted the Gevgelija fence and areas around it. First, on March 15, a mysterious group of unknown activists handed out maps with text in English and Arabic among migrants in the Eidomeni camp, advising them to cross the Suva Reka beyond the border fence. The information wrongly told migrants that the river would be dry, and three migrants drowned in the incident. Further, Macedonian police and army had to intercept and return large numbers of migrants and foreign activists and journalists who had penetrated national territory illegally. This had to be handled in a delicate way (and was so) despite the weaponization of media that followed (e.g. stories promoted by activists that suggested they had suffered harm at the hands of police).

Secondly, the April 10 border attack on the fence at Eidomeni also had an organized, PsyOps element and was also preceded by disinformation. The attack, while unsuccessful, did significant damage to border police equipment and resulted in injuries to police and soldiers from an increasingly organized and violent migrant wave. It was only after Greek authorities had managed to close the camp and resettle its inhabitants that chronic security threats were removed from the border. Numerous daily attacks of a smaller nature had occurred almost daily until that point, and over 11,700 illegal 
migrants were discovered and returned in the period between March 8 and May 12, 2016 alone. In several cases, there was evidence that foreign actors were guiding these efforts. Intelligence indicates a disinformation campaign led by unknown actors (possibly of a German, Italian, British or other origin).

\section{Efforts that Were Made to Neutralize these Threats}

Despite the severity of these hybrid threats, the Macedonian authorities took specific measures to avert them. Aside from closer collaboration with Bulgarian services from spring 2016, locally at the border with Greece they took a more proactive approach to intelligence-gathering and assessing what violent actions were being made by migrants and activist supporters. This also involved countering disinformation, since most of the major security incidents were the result of deliberately spreading false information among the migrants by unknown actors.

Anticipation of attacks and containing groups with peaceful means, and removal of negative actors (i.e., banning activists from re-entering the country for a period of time) were effective countermeasures. Further intelligence gathering was undertaken to ascertain other motivations and future security events involving migrants.

However, despite these successes, enormous 'collateral damage' was done to the state in weaponized media influencing diplomats and public opinion in different countries. This caused an unnecessary diplomatic headache and impeded the normal workings of government for short but crucial periods.

\section{Macedonian-Bulgarian Security Cooperation during the Migrant Crisis and Expected Trends}

Unlike with Greece, Macedonia had strong and constant cooperation with Bulgaria during the crisis. After closure of the border, Bulgaria-Macedonia joint air-land security cooperation began in mid-March 2016, with humanitarian aid from Bulgaria as well. Good political and intelligence cooperation throughout the migration crisis makes it a good example for other neighboring countries security cooperation.

At the EU Bratislava meeting on September 16, 2016, Bulgaria requested 160 million Euros support from the EU for dealing with the migrant crisis at the border. Bulgaria must cope with all identified threats, and Frontex and other EU support was not proven successful elsewhere. It is thus possible that the more willing and regionally aware countries of the Viserad group (the Czech Republic, Hungary, Poland, and Slovakia), Serbia and Macedonia may present better cooperation options.

Any security threat assessment involves political expectations (Turkey, Libya, Germany, etc.) and is thus going to be open to constant modification as the pace of real- 
world events quickens in a post-Brexit Europe. Continued close intelligence sharing and practical cooperation with all neighbors is needed to meet this threat, especially considering that we have not yet seen the worst of the migrant flows into the Balkans. Much depends now on larger external factors, and the only thing that Balkan countries can do is prepare as best as possible for security challenges and political factors that influence them. The cooperation of Macedonia and Bulgaria is in this regard a success story for such future work.

\section{References}

1.New York Declaration for Refugees and Migrants, A/RES/71/1, Resolution adopted by the General Assembly on 19 September 2016, UN General Assembly, available at www.un.org/ en/ga/search/view_doc.asp?symbol=A/RES/71/1\&=E\%20, accessed April 21, 2018.

2.Christopher Deliso, Migration, Terrorism and the Future of a Divided Europe: A Continent Transformed (Santa Barbara, CA: Praeger Security International, 2017).

3.Roderick Parkes, Nobody Move! Myths of the EU Migration Crisis, Chaillot Papers 143 (Paris: EU Institute for Security Studies, December 2017), available at www.iss.europa.eu/ content/nobody-move-myths-eu-migration-crisis, accessed April 21, 2018.

\section{About the Author}

Chris DELISO is an American analyst and author covering Balkan security, politics and intelligence issues, among others, for almost two decades from the region. He has published numerous articles and books, most recently a monograph titled Migration, Terrorism and the Future of a Divided Europe: A Continent Transformed (PSI, 2017). He holds an MPhil with Honors in Byzantine Studies from Oxford University. 